\title{
The Impact of Parental Involvement and Expectations on Elementary School Students' Academic Achievement
}

\author{
E.Nihal Lindberg, Kastamonu University, https://orcid.org/0000-0003-4028-8742 \\ PInar Güven, MNE, https://orcid.org/0000-0002-0892-4991
}

\begin{abstract}
This study is a correlational research that aims to define the relationship between parental involvement, parental expectations and elementary school students' academic success. In defining the sample of the study, it was aimed to ensure the diversity of socioeconomic level and sociocultural status. Totally, 420 parents have voluntarily participated in the research after the purpose of the study explained to them. The data was gathered with the Scale for School and Family Involvement in Elementary Schools, subscale of parents developed by Sheldon and Epstein's (2007) which has been adapted into Turkish by Oğuz (2012). While there was only one dependent variable of the study (academic success), there are six independent variables (parents' educational status, family SES, parents' gender, child's gender, parental involvement, parental expectation). Within the research, independent samples t-test and Chi-square independence test were used. Moreover, logistic regression analysis was performed in order to define the power of predictability of the variables. Results showed that, there are not significantly statistical relations between academic success and parents' gender, children's gender, parental involvement at school. On the other hand, it has been concluded that parents' educational status, family SES, parental expectation and parental involvement at home are significantly correlated with children's academic success. It was seen that the most important predictor of a child's academic success is parental expectations. Based on the results, recommendations were developed for parents, schools and researchers.
\end{abstract}

Keywords Academic success, Parental cognitions, Parental expectations, Parental Involvement

\author{
(10) \\ İnönü University \\ Journal of the Faculty of \\ Education \\ Vol 22, No 1, 2021 \\ pp. $809-840$ \\ DOI: $10.17679 /$ inuefd. 8882
}

Article Type:

Research article
Received : 28.02.2021

Accepted: 29.04 .2021

Suggested Citation

Lindberg,E.N. \& Guven, P. (2021). The Impact of Parental Involvement and Expectations on Elementary School Students' Academic Achievement, Inonu University Journal of the Faculty of Education, 22(1), 809-840. DOI: 10.17679/inuefd.888292 This article was produced from the master's thesis accepted by the Kastamonu University of Social Sciences Institute in June, 2019. It was presented at the $12^{\text {th }}$ Biennal Conference of ERNAPE held on Gdansk, Poland on 08-10 September 2019. 


\title{
Ana Baba Katılımı ve Beklentilerinin Ilköğretim Öğrencilerinin Akademik Başarısı Üzerindeki Etkisi
}

\author{
E.Nihal Lindberg, Kastamonu Üniversitesi, https://orcid.org/0000-0003-4028-8742 \\ PInar Güven, MEB, https://orcid.org/0000-0002-0892-4991
}

Öz

Bu çalışma, ilkokul ve ortaokul öğrencilerinin akademik başarıları ile ana babalarının katılımları ve gelecekteki eğitimlerine yönelik beklentileri arasındaki ilişkinin ortaya konmasını amaçlayan ilişkisel bir araştırmadır. Çalışma .... ilinde yürütülmüş, araştırmanın örnekleminin belirlenmesinde sosyoekonomik düzey ve sosyokültürel çeşitliliğin sağlanması dikkate alınmıştır. Çalışmaya 420 ana baba, araştırma amacı açıklandıktan sonra gönüllü olarak katılmıştır. Çalışmanın verileri, Sheldon ve Epstein (2007) tarafından geliştirilip Oğuz (2012) tarafından Türkçeye uyarlanan "ilköğretimde Okul ve Aile Katılım Ölçeği"nin Veli Alt Ölçeği yoluyla elde edilmiştir. Çalışmanın tek bir bağımlı değişkeni (akademik başarı) varken, altı bağımsız değişkeni (ana babanın eğitim düzeyi, ailenin gelir düzeyi, çocuğun cinsiyeti, ana babanın cinsiyeti, ana baba katılımı, ana baba beklentisi) vardır.

Araştırma kapsamında değişkenler arasındaki ilişkilerin belirlenmesinde t testi ve Ki-Kare kullanılmış; ilişkili değişkenlerin akademik başarıyı yordama düzeylerinin belirlenmesinde ise Lojistik regresyon analizi kullanılmıştır. Analizler sonunda; akademik başarı ile çocuğun, ana babanın cinsiyeti ve ana babanın eğitime okulda katılımı arasında anlamlı bir ilişki olmadığı sonucuna ulaşılmıştır. Bununla birlikte, akademik başarı ile ana babanın eğitim düzeyi, ailenin gelir düzeyi, ana baba beklentisi ve ana babanın eğitime evde katılımı arasında olumlu yönde bir ilişki bulunmuştur. Son olarak, bir öğrencinin akademik başarısını yordayan en önemli değişkenin ana babanın yüksek beklentileri olduğu ortaya konmuştur. Sonuçlar temelinde ana baba, okul ve araştırmacılar için öneriler gelişsirilmiştir.

Anahtar Kelimeler: Akademik Başarı, Ana baba bilişleri, Ana Baba Beklentisi, Ana Baba Katılımı.

\author{
İnönü Üniversitesi \\ Eğitim Fakültesi Dergisi \\ Cilt 22, Sayı 1, 2021 \\ ss. $809-840$
}

DOI: $10.17679 /$ inuefd. 8882

Makale türü:

Araştırma makalesi

Gönderim Tarihi :

28.02.2021

Kabul Tarih

29.04.2021

Önerilen Atıf:

Lindberg,E.N. \& Guven, P. (2021). The Impact of Parental Involvement and Expectations on Elementary School Students' Academic Achievement. Inönü Üniversitesi Eğitim Fakültesi Dergisi, 22(1), 809-840. DOI: 10.17679/inuefd.888292

Bu makale Kastamonu. Üniversitesi, Sosyal Bilimler Enstitüsü tarafından Haziran, 2019 tarihinde kabul edilen yükseklisans tezinden üretilmiştir. 08-10 Eylül 2019 tarihlerinde Gdansk, Polonya.'da gerçekleştirilen $12^{\text {th }}$ Biennal Conference of ERNAPE'de sözlü bildiri olarak sunulmuştur. 


\section{The Impact of Parental Involvement and Expectations on Elementary School Students' Academic Achievement}

Theorists investigating human behavior from the perspective of contextual features emphasize that the personal characteristics of an individual, as well as his/her interactions with others, play an important role in the acquisition of behavior. Vygotsky (1978) stated that the interactions between a child and his/her parents help with the acquisition of instruments that mediate the learning process and new learning. Moreover, these interactions are affected by the parents' values and beliefs about education and childrearing, and they are shaped in line with them. Parents' perceptions of their parental role, values related to childrearing, expectations about the child's education, and casual attributions regarding a child's development are related to these beliefs and values and are discussed under the concept of parental cognition (Valsiner, 1988). Parental cognition is important since it influences all the behaviors of parents supporting a child's education and development. The present study examines parental cognition (specifically, parental expectation) in terms of academic achievement and uses "parents' educational status," "family socioeconomic status (SES)," and "parental involvement (PI)" as variables.

\section{Parental Expectation}

In their meta-analysis studies, Fan and Chen (2001) and Jeynes (2007) argued that the most important parental variable playing an effective role in academic achievement is the parent's expectations regarding the educational performance of a child. Carpenter (2008) defined parental expectation, which is one of the parental cognitions, as predictions and judgments towards the child's future academic achievement. These expectations include all the judgments and beliefs about a child's performance at school or the level of education he/she can complete as well as the behaviors supporting them. However, parental expectations are different from parental aspirations related to the child's education. Educational expectations are defined as judgments and beliefs with more realistic bases for 
the future, whereas aspirations are defined as the wishes expressed by parents based on social norms regarding the importance of schooling and their own aims (Yamamoto \& Holloway, 2010).

Expectations have an important effect on parental behaviors related to both allocating resources to support the child at a certain academic level and evaluating the child's academic competencies. Moreover, the parents' actions addressing the academic achievement mediate them to establish new expectations on their children or reconstruct the current expectations (Valsiner, 1988). However, previous studies in the literature revealed that parental expectations are formed under the effect of variables such as family SES (Davis-Keen, 2005; Mistry, White, Benner, \& Huynh, 2009), parents' educational status (Daymaz, 2012; DavisKeen, 2005; Davis-Kean et al., 2003; Yamamoto \& Holloway, 2010), child's gender (Jacobs et al., 2005; Räty et al., 2002), and previous achievements of a child (Englund et al., 2004; Neuenschwander et al., 2007).

\section{Parental Involvement (PI)}

The environment and conditions provided by parents at home are as important as the school in the academic achievement of a child. The parent needs to motivate children for school studies, help them repeat and reinforce what they have learned, guide them, and make an effort to learn what subjects they learn at school, what they should learn, what the tools needed are, and how they can help their children in cooperation with the school. These practices are all defined as parental involvement (PI). From a general perspective, $\mathrm{PI}$ can be described as a process-oriented relationship that is based on reciprocal cooperation and partnership between parents and schools. Hoover-Dempsey et al. (2005) stated that PI includes behaviors and cognitions related to supporting the education and development of a child. In this regard, motivational beliefs defined by parents' self-efficacy beliefs and role perceptions, their own school experiences, and perceptions of being invited by the school/teacher of their children for PI are recognized as the most important components of PI. 
Epstein (2010) defined PI as a system in which school, family, and society function together as the parts of overlapping spheres to support the development and education of students. In this system, it is considered important for everyone to be active and to establish a partnershipbased on constant relationship rather than cooperation. Green et al., (2007) discussed parents' home- and school-based involvement practices separately. PI at home includes practices such as helping with homework, providing tools the child needs, creating a supportive environment at home, etc. However, the most important example of $\mathrm{PI}$ at home is constant communication with children about school. This communication entails both having accurate and sustained information about the progression of students and taking necessary measures by receiving ontime information about the problems that the child faces (Hornby, 2011; Jeynes, 2011). On the other hand, school-based PI includes practices such as meetings with teachers, voluntary help for teachers on school trips, and making efforts to meet the needs of schools.

\section{Significance and Purpose of the Research}

In the literature, besides the individual factors affecting academic achievement, and parental characteristics have also been frequently discussed in recent years. Family SES, parents' gender, parental educational status, $\mathrm{PI}$, and parental cognitions (expectation, attribution, motivational beliefs about involvement, etc.) are among the variables related to parents and family.

In previous studies carried out in different cultures, it was emphasized that the gender of parents plays an effective role in academic achievement, and this is related to the differences in the parents' cognition regarding the subject. Accordingly, it can be seen that mothers take more responsibility and are more effective in their child's education when compared to fathers (Deslandes, 2009; Hornby, 2011; Kim, 2018). It is understood that this applies even to countries such as Sweden, where there are many legal regulations on gender equality (Gurdal, 2015). Studies have revealed that the difference is substantially related to the traditional gender roles attributed to women and men. Another remarkable finding concerns 
the effect of parents' educational status and family SES on academic achievement. The assumption that a child of a family with a high socio-economic level will have greater academic success has been emphasized for many years in the literature. The main point here is that family SES affects the accessibility of social, cultural, and academic resources that are important and/or necessary for children's development and education. Furthermore, as Şirin (2005) emphasized, it can be seen that family SES has a significant effect when evaluated alongside the educational status of parents. In other words, when compared to parents with low educational status and high SES, parents with a high educational status and moderate to high SES have more advantages in terms of supporting their children's education and development.

It is emphasized in the literature that $\mathrm{PI}$ is one of the most important variables affecting the academic achievement of students at any educational level (Englund et al., 2004; Fan \& Chen, 2001; Hill \& Tyson, 2009; Şad, 2012; Weber, 2010). Furthermore, it can also be seen that several parent-related variables affect the level and quality of PI. The first one of these variables is parents' educational status. It has been shown that as the education level of parents decreased, PI also decreased (Ramirez, 2003; LaRocque et al., 2011; Flynn, 2007). This finding can be explained by the limited perception of parents about their role or efficacy in PI (Amatea \& West-Olatunji, 2007; Hoower-Dempsey et al., 2005; LaRocque et al., 2011; Ramirez, 2003). Besides this, it has been reported that home- and school-based PI practices have different effects on children at different education levels (Çubukçu \& Girmen, 2006; Flaxman \& Inger, 1991; Vaden-Kiernan \& Chandler, 1996). For students at the elementary school level, school-based PI positively affects the student's motivation about learning and schooling as well as their academic achievement (Englund et al., 2004; Gonzales-DeHass et al., 2005; PavalacheIlie \& Tirdia, 2015). However, this effect is not valid for high school students. Accordingly, it was revealed that $\mathrm{Pl}$ at home has a positive effect on school attendance and motivation for 
learning as well as academic achievement at the high school level (Clinton \& Hattie, 2013; Gonzales-DeHass et al., 2005; Lam \& Ducreux, 2013; Sarpkaya, 2007).

Studies have shown that the children of parents with high expectations are more successful at school when compared to the children of parents with low expectations (Kirk et al., 2011; Patrikakou, 2008; Yan \& Lin, 2005; Wilder, 2014). Morera et al. (2015) conducted a meta-analysis on 37 studies carried out at the preschool and primary and secondary school levels between 2000 and 2013. The authors concluded that as parental supervision over the education of children increased, academic achievement also increased. However, the most remarkable finding of the study was the effect of parents' direct mutual educational and social interactions with their children, which accompany the parents' high expectations about their children's education, on academic achievement. It was stated that the effect of mutual interaction on academic achievement is more significant when compared to other familyrelated variables.

There are few studies examining the effects of PI on children's academic achievement in Turkey (Aktamış et al., 2008; Argon \& Kıyıcı, 2012; Çelenk, 2003; iflazoğlu-Şaban \& Şeker, 2010; Kotaman, 2008; Şad, 2012). Analyses performed on the data obtained from Turkish students' schools and family characteristics on exams such as the PISA and TIMMS (Taş et al., 2016; Yıldırım et al., 2013) revealed that the most important variables affecting achievement are the family-related variables. Although there are two studies on parental cognition in the Turkish literature (Lindberg et al., 2019; Kaya \& Bacanlı, 2016), it was not encountered with a study examining its direct effect on academic achievement. Accordingly, the present study aims to examine the effects of $\mathrm{PI}$ and parental expectations on the academic achievement of students aged between 10 and 13 . The research questions are as follows:

1. Is there a significant relationship between parents' gender, students' gender, and academic achievement? 
2. Is there a significant relationship between family SES, parents' educational status, parents' expectations, and academic achievement?

3. Are family SES, parents' educational status, $\mathrm{PI}$, and parents' expectation significant predictors of academic achievement?

4. How accurately can the variables of family SES, parents 'educational status, PI, parents' expectations distinguish students with low and high academic achievement?

\section{Methodology}

This study is a correlational study aiming to examine whether academic achievement dependent variable- is predicted by the parents' educational status, family SES, parents' and child's gender, $\mathrm{PI}$, and parental expectation -independent variables-.

\section{Participants}

A stratified sampling method was used in the present study. After the first interviews with the relevant units in the Kastamonu Provincial Directorate of National Education, residential areas differing in terms of socioeconomic and socio-cultural characteristics were determined. As in determining the regions, socioeconomic and sociocultural level differences were taken into consideration in determining the primary and secondary schools, where data would be collected. In calculating the sample size, the reliability level was set to be $95 \%$ and the mean deviation value was set at five. Thus, the sample size was calculated to be 375 . However, it was decided to increase the sample size to 450 in order to handle the possible missing data. After the sample size was determined, the students were distributed equally according to their grade levels.

Following this step, the relevant school principals were contacted; parents were informed about the purpose of the research and contact information of the researchers (by principals, teachers, or school counselors). The scales were then delivered to parents through students. On the first page of the scale form, information about the researchers and the 
purpose of the study was given along with researcher contact information. In addition, it was stated that attendance in the study was completely voluntary and that filling out the scales would be considered as acceptance for attendance. Excluding 30 invalid scales (filled incompletely or with the same answers always marked) from 450 forms submitted, 420 forms were used for analyses. Table 1 provides information about the participants whose answers were valid.

Table 1.

Information About Participants

\begin{tabular}{|c|c|c|c|}
\hline Variables & Categories & $\mathbf{n}$ & $\%$ \\
\hline & 1. Mother & 246 & 58.6 \\
\hline & & & \\
\hline & 2. Father & 174 & 41.4 \\
\hline \multirow{2}{*}{ Child's Gender } & 1. Male & 181 & 43.1 \\
\hline & 2. Female & 239 & 56.9 \\
\hline \multirow{3}{*}{ Parents' Educational } & 1. Low (Primary school graduate /Person who & & \\
\hline & drop high school out) & 151 & 36.0 \\
\hline & & & \\
\hline \multirow[t]{4}{*}{ Status } & 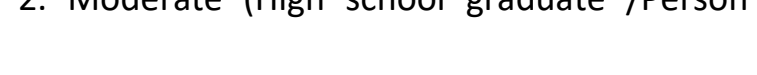 & 116 & 27.6 \\
\hline & who drop college out) & & \\
\hline & 3. High (College /Master-Doctorate degree) & 153 & 36.4 \\
\hline & 1. Low (890 TL and less / 890-1000 TL) & 147 & 35.0 \\
\hline \multirow[t]{2}{*}{ Family SES } & 2. Moderate (1000-2000 TL / 2000-3100 TL) & 134 & 31.9 \\
\hline & 3. High (3100-5000 TL / $5000 \mathrm{TL}$ and more) & 139 & 33.1 \\
\hline
\end{tabular}

As can be seen in Table 1, mothers constituted the majority of participants. Moreover, although there was a difference between the parents' educational statuses, they were mostly university graduates. Finally, the family SES data suggested that most of the participants were in the low-income group. 


\section{Data Collection}

When collecting data on academic achievement, the parents could not be asked about their children's year-end GPAs since the study data were collected during the spring semester. For this reason, parents were asked about several course grades based on their child(ren)'s performance. The statements in the Ministry of National Education's (MNE) Regulation on Primary Education Institutions, which includes the definitions of course grades, were used as criteria in forming the options for this question (MNE, 2014). Thus, the options for academic achievement were Mostly 1 (weak), Mostly 2 (average), Mostly 3 (medium), Mostly 4 (good), and Mostly 5 (excellent).

The Parents Scale for School and Family Involvement in Elementary Schools, which was developed by Sheldon and Epstein (2007) and adapted to Turkish by Oğuz (2012), was used in collecting the data on PI. Confirmatory factor analysis was used to determine structural validity in the adaptation of the scale into Turkish culture. The analyses showed that an $\chi 2$ value on the scale was significant: $\chi 2(s d=2330)=4713.74, p<.01$. Additionally, the results related to the fit indices were determined as RMSEA .059, SRMR .060, CFI .95, and GFI .69. While the Cronbach's Alpha internal consistency coefficient of the whole scale was found to be .95 in the adaptation study, the internal consistency coefficient of the PI at school was determined to be .72 and $\mathrm{PI}$ at home to be .92. In this study, the total Cronbach's Alpha for PI at school and PI at home was calculated as .93. PI at school includes four items defining the parents' opinions about PI activities provided by the school. Items for PI at home include questions such as Do you check whether your child finishes his/her homework and Do you read books with your child. Responses for both factor were obtained through a 4-point Likert-type scale ranging between Every day and Very often - Never.

Finally, parents were asked about the level of education at which they think their children will graduate in order to determine parental expectations. The responses were 
obtained through the options of Middle/Secondary School, High School, Vocational/Technical High School, Vocational/Technical College, University, and Master's Degree/Doctorate.

\section{Data Analysis}

Before analyzing the data, normal distribution curves and skewness and kurtosis with Kolmogorov-Smirnov (K-S) test values were examined in order to determine the missing data related to responses and to determine whether the data were distributed normally.

Table 2.

Skewness and kurtosis values of the scale scores and the significance level results of KolmogorovSmirnov test

\begin{tabular}{lcccc} 
& & & \multicolumn{1}{c}{ Kolmogorov- } \\
& $\mathrm{N}$ & Skewness & Kurtosis & $\mathrm{P}$ \\
\hline Total score & &,- 173 &,- 649 & .010 \\
PI at School & 420 &, 229 & $-1,118$ & .00 \\
PI at Home & &,- 352 &,- 681 & .00 \\
\hline
\end{tabular}

According to the results presented in Table 2, it can be seen that, although the data were not normally distributed, skewness and kurtosis values are determined to be more reliable sources of information for normality. In the present study, skewness and kurtosis values were reported to be within the acceptable limit, which was +/- 1.50 (Tabachnick \& Fidell, 2007). In this regard, the Chi-square independence test was used in order to determine the correlation between dependent and independent variables. In Chi-square tables, the Phi value was used when the categories of the variables were $2 X 2$ and Cramer's $V$ value was used when the variables were $2 X 4$. Additionally, an independent samples $t$-test was used to 
determine whether there was a significant difference between the mean values of academic achievement and $\mathrm{PI}$ at school and $\mathrm{PI}$ at home.

In this study, logistic regression analysis was performed. As Palant (2016) stated logistic regression analysis allows to show how well the group of predictor variables (PI at school, $\mathrm{PI}$ at home, educational status, SES, parental expectation, parent gender) predicts or explains the categorically dependent variable (academic achievement). On the other hand, there are several assumptions required for conducting a logistic regression analysis. The first is about number or ratio of individuals in each category. In this regard, it is important to carry out studies with large samples to increase the reliability of logistic regression analysis. In this study, it is found that there are enough number of participants in each category. The second assumption is that the model that formed as a result of logistic regression analysis, is sensitive toward the extreme values in the data. The last assumption is that logistic regression is a type of multiple regression (Çokluk, 2010). Thus, it is sensitive toward a high correlation between independent/predictor variables because high correlation causes multi-collinearity problems between the predictor variables (Çokluk et al., 2014). Eigenvalues state indices, and variance rates, which were determined to examine the multi collinearity problem between the variables, are presented in Table 3.

Table 3.

Eigenvalues, state indexes and variance rates

\begin{tabular}{|c|c|c|c|c|c|c|c|c|c|}
\hline \multirow{4}{*}{ Dimension } & \multirow[b]{2}{*}{ Eigen } & \multirow[b]{2}{*}{ State } & \multicolumn{7}{|c|}{ Variance Rates } \\
\hline & & & Constant & $\mathrm{Pl}$ at & $\mathrm{PI}$ & Educ. & Income & Par. & Par. \\
\hline & Value & Index & & School & at & Status & & Expec. & Gender \\
\hline & & & & & Home & & & & \\
\hline 1 & 5.665 & 1.000 & .00 & .00 & .00 & .01 & .01 & .00 & .01 \\
\hline 2 & .540 & 3.240 & .00 & .00 & .00 & .04 & .02 & .00 & .90 \\
\hline 3 & .424 & 3.653 & .01 & .01 & .00 & .23 & .27 & .01 & .04 \\
\hline
\end{tabular}




\begin{tabular}{llllllllll}
\hline 4 & .240 & 4.862 & .00 & .00 & .00 & .68 & .69 & .00 & .01 \\
\hline 5 & .085 & 8.155 & .00 & .12 & .01 & .02 & .02 & .74 & .01 \\
\hline 6 & .029 & 13.995 & .71 & .46 & .01 & .00 & .00 & .24 & .03 \\
\hline 7 & .017 & 18.125 & .29 & .41 & .97 & .01 & .00 & .01 & .00
\end{tabular}

As seen in Table 3, state index values are lower than 30 , and there is no value that is significantly higher than others. Moreover, the highest variance of each predictor variable is loaded to a separate eigenvalue. From this aspect, it can be seen that every predictor variable explains another dimension of the variance (Çokluk, 2010). The standard errors, tolerance, VIF values of the predictor variables, and binary correlations between the variables are presented in Table 4.

Table 4.

Standard error, tolerance and VIF values

\begin{tabular}{|c|c|c|c|c|c|c|c|}
\hline \multirow[b]{2}{*}{ Predictor Variables } & \multirow[b]{2}{*}{$\beta$} & \multirow{2}{*}{$\begin{array}{c}\text { Standard } \\
\text { Error }\end{array}$} & \multirow[b]{2}{*}{ Tolerance } & \multirow[b]{2}{*}{ VIF } & \multicolumn{3}{|c|}{ Correlations } \\
\hline & & & & & 1 & 2 & 3 \\
\hline 1. PI at school & -.012 & .010 & .602 & 1.662 & .079 & -.010 & -.009 \\
\hline 2. PI at home & .127 & .004 & .569 & 1.757 & .191 & .102 & .096 \\
\hline 3. Educational & .129 & .030 & .789 & 1.268 & .197 & .121 & .114 \\
\hline Stat. & & & & & & & \\
\hline 4. Family SES & -.006 & .031 & .802 & 1.248 & .102 & -.006 & -.006 \\
\hline 5. Par. Expec. & .243 & .032 & .884 & 1.131 & .301 & .237 & .228 \\
\hline 6. Par. Gender & -.044 & .047 & .975 & 1.025 & -.059 & -.047 & -.044 \\
\hline
\end{tabular}

As seen in Table 4, the tolerance values of all predictor variables are higher than .1. Moreover, the VIF values are lower than 10. Çokluk (2010) stated that tolerance values higher 
than .1 are an intended situation in multicollinearity problems. This finding suggested that there was no such problem, and the logistic regression analysis could now be performed.

\section{Findings}

\section{Correlations Between Dependent Variable and Independent Variables}

According to the results of the Chi-square test, no significant correlation was found between academic achievement and parents' gender $\left(x^{2}=.026 ; p>.05\right)$ or the child's gender $\left(x^{2}=1,49 ; p>.05\right)$. In addition, it was determined that mothers' mean values were higher regarding both high and low academic achievements. In analyses of the children's gender, it was determined that female or male gender did not cause any difference in academic achievement. Significant correlations were found between the variables of parents' educational status, family SES, parental expectation, and academic achievement. Moreover, according to the results of the independent samples $t$-test conducted in order to reveal whether academic achievement varies depending on PI at school, no statistically significant difference was found between the variables $(t=-1,61 ; p>.05)$. The eta square value, which was used in order to calculate the effect size of this finding, was calculated to be $\eta 2=0.03$.

Considering the difference between mean scores, it was determined that the values were close to each other and, thus, $\mathrm{PI}$ at school did not cause any significant difference in academic achievement.

The Chi-square test results showed that there was a significant correlation between academic achievement and parents' education level $\left(x^{2}=17.20 ; p<.05\right)$. The results are presented in Table 5.

Table 5.

The results of the Chi-square test for academic achievement and parents' education level

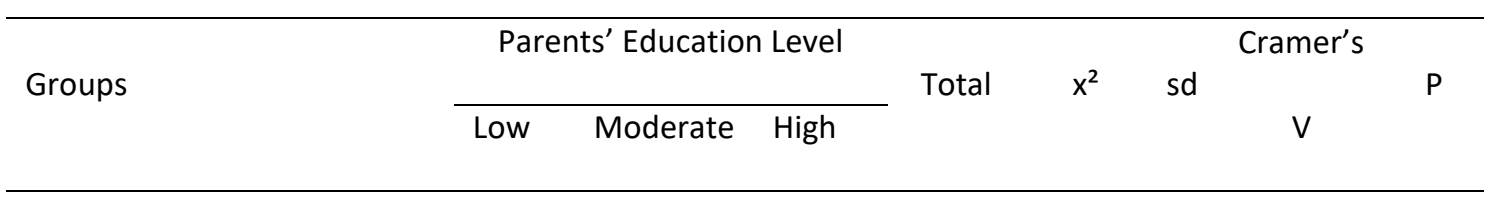




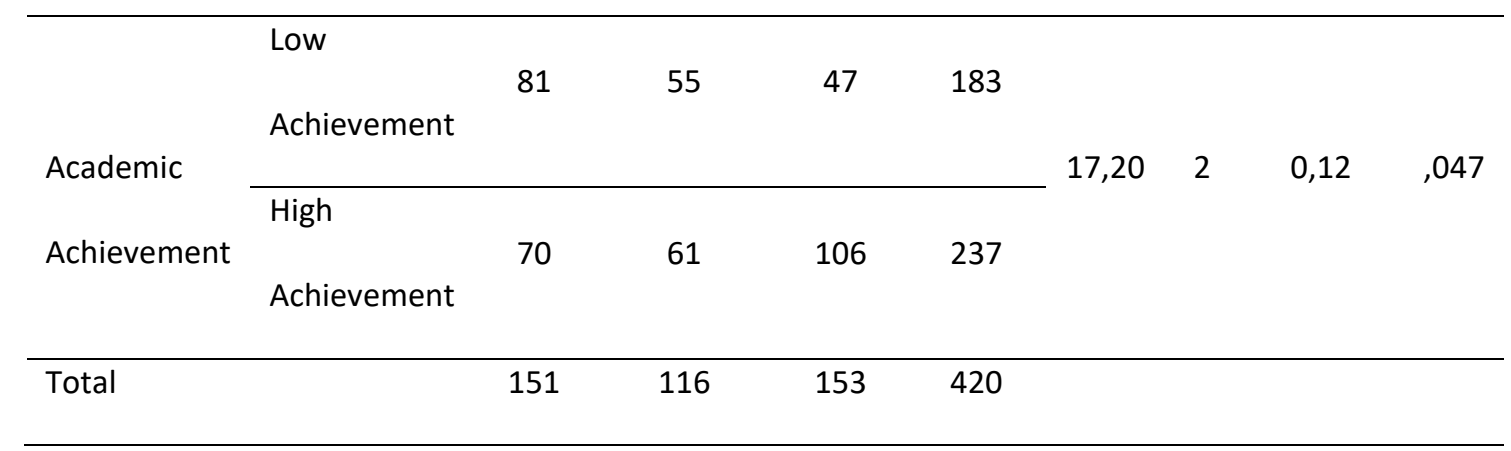

The results showed that there was a significant difference between being in the high achievement groups of children with poorly educated parents and children with highly educated parents. Similarly, a significant correlation was specified between academic achievement and family SES $\left(x^{2}=6.10 ; p>05\right)$. The results are presented in Table 6 .

Table 6.

The results of the Chi-square test for family SES

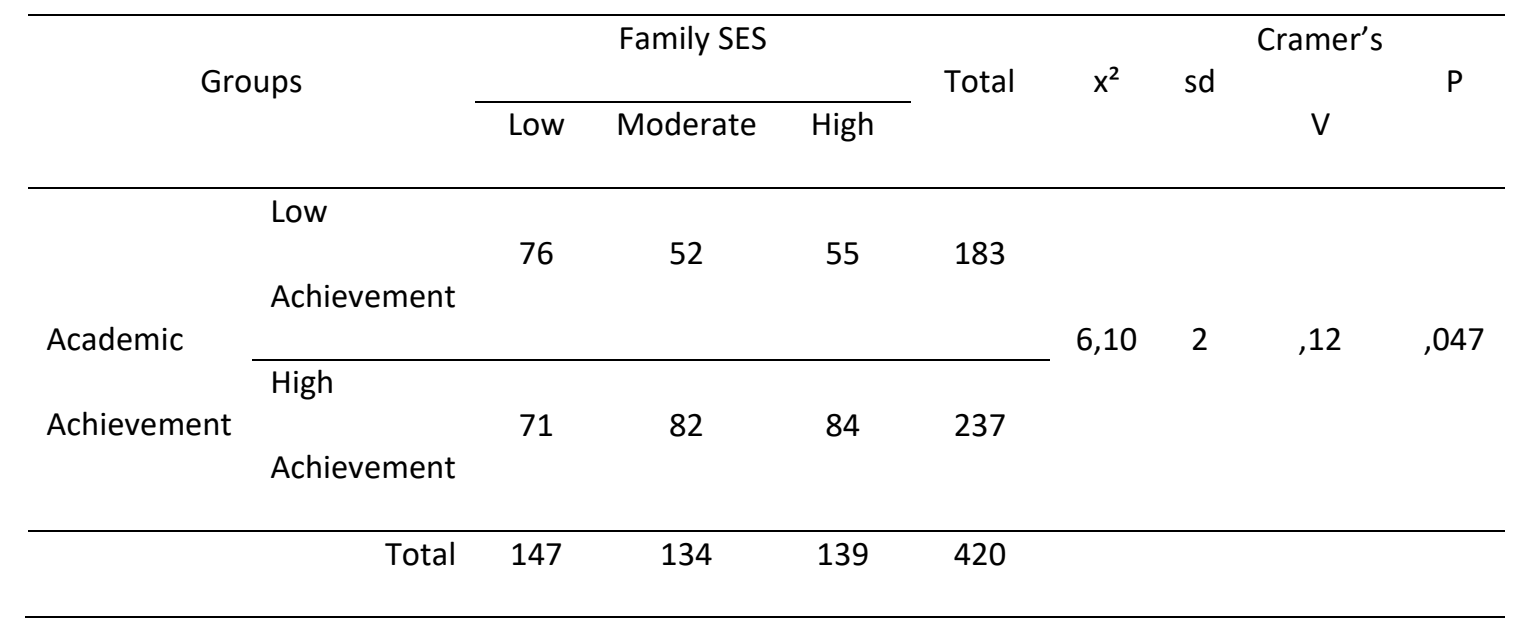

It is determined that there is a significant correlation between the parents' expectations and academic achievement $\left(x^{2}=40,24 ; p<.05\right)$. The results are given in Table 7.

Table 7.

The results of Chi-square test for parental expectations 


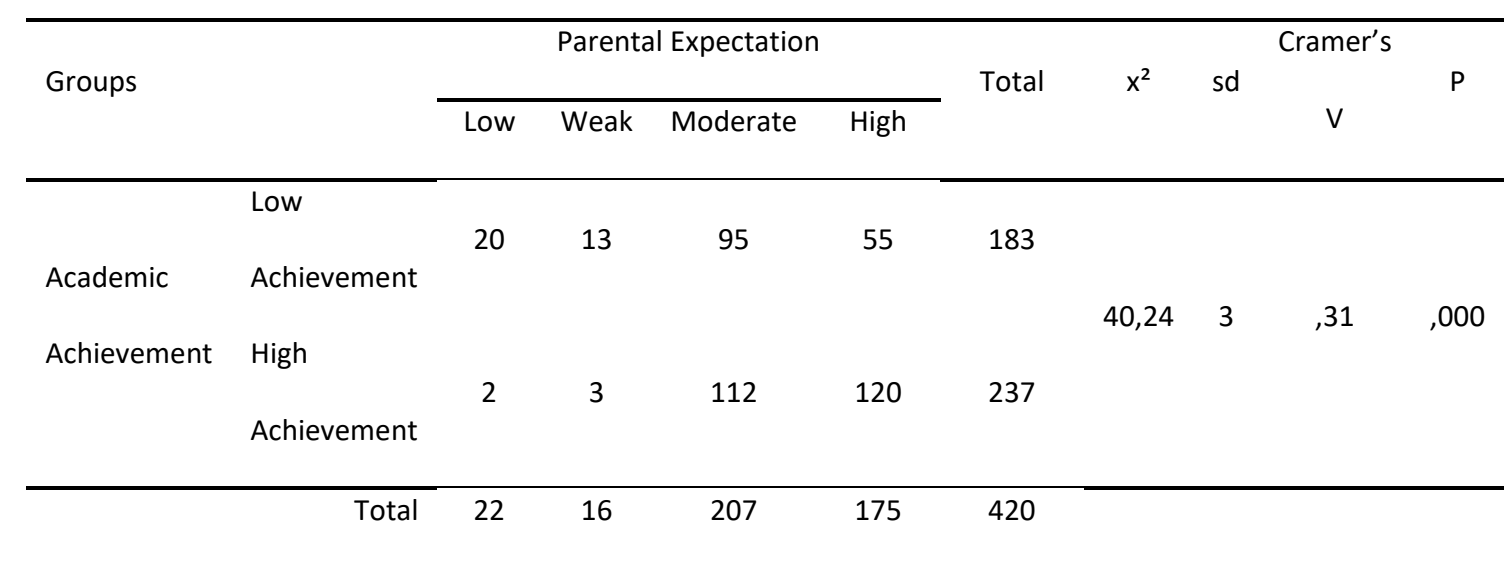

As can be seen in Table 7, when parents' expectations are at moderate to high levels, the ratios between their children's being at low or high achievement levels vary significantly. Moreover, when parents' expectation levels are low or weak, a decrease was observed in their children's rate of being in a high achievement state.

Finally, the results of the independent samples $t$-test showed that there was a statistically significant difference between the variables $(t=-3.92 ; p<.01)$. The analysis results are presented in Table 8.

\section{Table 8.}

The results of the independent samples T-test for PI at home

\begin{tabular}{|c|c|c|c|c|c|c|c|c|}
\hline & \multicolumn{5}{|l|}{ Academic } & \multicolumn{3}{|c|}{ T-test } \\
\hline & \multirow[b]{2}{*}{ Achievement } & \multirow[t]{2}{*}{$\mathrm{N}$} & \multirow[t]{2}{*}{$\bar{x}$} & \multirow[t]{2}{*}{ Sd } & \multirow[t]{2}{*}{ Se } & & & \\
\hline & & & & & & $\mathrm{T}$ & $\mathrm{Sd}$ & $P$ \\
\hline & Low & & & & & \multirow{7}{*}{$-3,92$} & \multirow{7}{*}{372,1} & \multirow{7}{*}{,000 } \\
\hline & & 183 & 38,1 & 8,74 & 64 & & & \\
\hline & Achievement & & & & & & & \\
\hline \multirow[t]{4}{*}{ PI at Home } & & & & & & & & \\
\hline & High & & & & & & & \\
\hline & & 237 & 41,3 & 7,97 & ,51 & & & \\
\hline & Achievement & & & & & & & \\
\hline
\end{tabular}

The eta square value, which was used in calculating the effect size of the determined difference, was calculated to be $\eta 2=0.12$. This result indicates that, contrary to $\mathrm{PI}$ at school, $\mathrm{PI}$ at home increases academic achievement. Furthermore, the positive correlation between $\mathrm{PI}$ at home and high academic achievement shows the importance of PI activities such as helping 
with homework and projects, checking homework, reading books together, talking about courses, discussing the day spent in school, etc.

\section{Prediction of Academic Achievements of Elementary School Students}

A regression model including the independent variables that had statistically significant correlations with academic achievement was formed according to the results of the analyses presented in the previous section. This model consists of four independent variables: $\mathrm{PI}$ at home, parents' educational status, parents' expectations, and family SES. Findings obtained from the logistic regression analysis are presented in Tables 9, 10, 11, and 12.

Table 9.

Summary of the Target Model

\begin{tabular}{lccc}
\hline Step & $(-2 \mathrm{LL})$ & Cox\&Snell $\mathrm{R}^{2}$ & ${\text { Nagelkerke } \mathrm{R}^{2}}^{2}$ \\
\hline 1 & 507,954 &, 149 & \\
\hline
\end{tabular}

According to Table 9, predictor variables explained $14.8-19.9 \%$ of the variance regarding academic achievement.

Table 10.

Hosmer and Lemeshow Test

\begin{tabular}{lccc}
\hline Step & Chi-Square & Sd & P \\
\hline 1 & 6,982 & 8 &, 539 \\
\hline
\end{tabular}

According to the table above, it can be seen that the Hosmer and Lemeshow test result is not significant $(p>.05)$. Thus, the model has an acceptable fit.

Table 11.

Classification Table Obtained as a result of Logistic Regression Model 


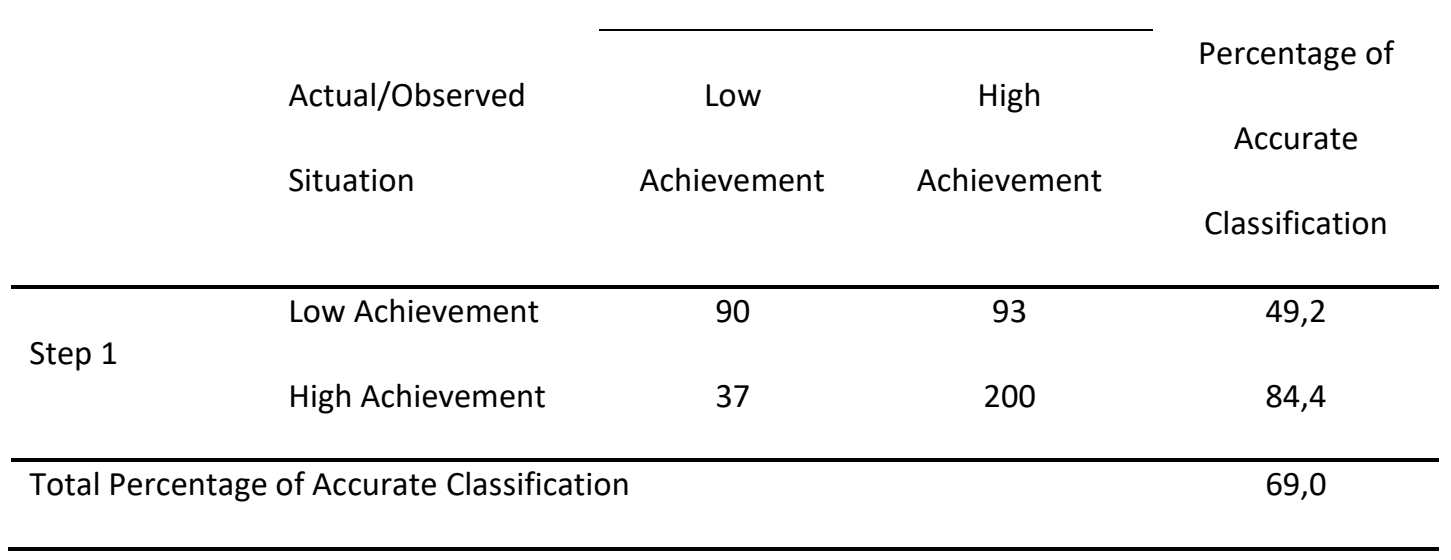

As seen in Table 11, the formed regression model accurately classified $49.2 \%$ of the students with low achievement and $84.4 \%$ of the students with high achievement.

Additionally, the model formed here accurately classified $69 \%$ of all participants (Çokluk et al., 2014).

Table 12.

Coefficient Estimates of the Target Model Variables

\begin{tabular}{|c|c|c|c|c|c|c|}
\hline Step & B & $\mathrm{Se}$ & Wald & sd & $\mathrm{p}$ & $\operatorname{Exp}(B)$ \\
\hline $\mathrm{PI}$ at Home & , 016 & ,015 & 1,156 & 1 & ,282 & 1,016 \\
\hline Par. Educ. Status (Low) & & & 7,770 & 2 & 021 & \\
\hline Par. Educ. Status (Moderate) & 452 & ,277 & 2,652 & 1 & ,103 & 1,571 \\
\hline Par. Educ. Status (High) & 787 & ,286 & 7,582 & 1 & ,006 & 2,196 \\
\hline Family SES (Low) & & & 2,584 & 2 & ,275 & \\
\hline Family SES (Moderate) & ,331 & ,278 & 1,420 & 1 & ,233 & 1,393 \\
\hline Family SES (High) &,- 086 & ,283 & 091 & 1 & ,763 & ,918 \\
\hline Par. Expectation (Low) & & & 18,611 & 3 & ,000 & \\
\hline Par. Expectation (Weak) & 679 & ,989 & 470 & 1 & ,493 & 1,971 \\
\hline Par. Expectation (Moderate) & 2,129 & ,770 & 7,649 & 1 & ,006 & 8,405 \\
\hline Par. Expectation (High) & 2,609 & ,782 & 11,136 & 1 & 001 & 13,580 \\
\hline Constant & $-4,978$ & 1,010 & 24,311 & 1 & ,000 & ,007 \\
\hline
\end{tabular}


According to Table 12, the major predictor of a child's high academic achievement is parental expectation. It was determined that, when parents have high expectations, their children show almost 14 times higher achievement when compared to children of parents with low expectations $(\operatorname{Exp}(B)=13.580)$. Academic achievement of children with parents who have a moderate level of expectation is eight times higher $(\operatorname{Exp}(B)=8.405)$. The high achievement possibility of a child with highly educated parents is almost three times higher when compared to the children of parents with low to moderate educational levels $(\operatorname{Exp}(B)=2.968)$.

\section{Discussion, Conclusion and Recommendations}

In the present study, the findings revealed that there was no relationship between academic achievement and parents' gender, which might be because of the majority of participants in the present study were mothers. Secondly, the difference may also be because of some traditional gender roles which they address the responsibilities concerning the education and development of children are mostly given to mothers. This may be due to a belief that mothers may have greater awareness and knowledge in this respect. For instance, Lee et al. (2007) noted that the roles of mothers in explaining the antisocial behaviors and social skills of children and those of fathers in explaining characteristics of children such as cognitive development and entrepreneurship may be more important than those of the other parent. In the present study, it was also determined that there was no relationship between children's gender and academic achievement. This may be related to the fact that the majority of the parents participating in the study had daughters and that the number of parents with sons was limited. However, it has also been stated in the literature that there was no significant difference between the genders in terms of general intelligence and achievement and that there may only be differences in specific subject areas (Batyra, 2017; Liu \& Lynn, 2015). 
In parallel with the literature, it was found that there was a positive and significant relationship between parents' educational status and academic achievement. Şirin (2005) stated that parents' educational status has a more important impact on academic achievement when compared to family's SES. However, in this study, a significant positive relationship was found between family's SES and academic achievement. This result could be interpreted as meaning that income level is important in terms of access to resources in Turkey, and therefore that a high family income positively affects the academic achievement of a child. In his study, Şirin (2005) found that students' grade level, ethnic origin, some student characteristics, and school environment affected the degree of correlation between SES and academic achievement.

PI was examined as home- and school-based participation in the present study. A significant relationship was found between academic achievement and PI practices at home, whereas no statistically significant relationship was found between academic achievement and school-based participation practices. There may be several possible explanations for this. The first may be that parents do not receive invitations or support from their schools and/or teachers for participation. Hoover-Dempsey et al. (2005) stated that parents' perception of being invited is a significant motivational belief influencing school-based participation. Another possible reason is that PI practices at school were insufficient. As both the Turkish and international literature emphasizes, $\mathrm{PI}$ is mostly performed at limited levels and as limited practices in all educational levels (Epstein, 2008; Çubukçu \& Girmen, 2006; Graue \& Brown, 2003; Hornby \& Lafaele, 2011; Sabancl, 2009). The last possible reason is related to the age group included in the present study. The literature on PI suggests that adolescents do not take kindly to school-based parental participation since they are in a period of identity-searching and experiencing vital physical changes (Comer \& Haynes, 1991; Patrikakou, 2008; Deslandes, 2009; Hornby, 2011; Stahl, 2012). Studies have shown that PI practices at home, especially those based on giving positive feedback about students' educational performance or guiding 
them for their future decisions and establishing mutual communication, have a very significant and positive impact on academic achievement (Gonzalez-DeHass et al., 2005; Hickman et al., 1995; Hill \& Tyson, 2009; Kuperminc et al., 2007).

In the present study, logistic regression analysis was performed in order to determine the predictive power of variables regarding academic achievement. Accordingly, as Fan and Chen (2001), Jeynes (2007), and Yamamoto and Holloway (2010) also revealed, it was found that the most important predictor of academic achievement is high parental expectation. Moreover, even moderate expectations were found to be a better predictor than all other variables (parents' and children' gender, family SES, parents' educational status, and PI at home and school) related to academic achievement. As Lenz (1999) has also highlighted, it was found that the possible reason for the effectiveness of expectations is mutual, open, and direct communications between child and parents. Lenz (1999) also stated that children demonstrate positive emotional and behavioral changes when they feel that they are supported and assisted by adults. Accordingly, high expectations basically affect a child's perception for her/his-self. Positive perceptions cause children to make efforts to be successful and, therefore, to make their parents happy. In previous studies, it was determined that this strong relationship between academic achievement and expectation also has a spiral aspect. Accordingly, it was found that academic achievement increases as the coherence between parental expectations and children's expectations about their own achievement increases. It seems that as the academic achievement increases, parental expectations are also getting higher (Goldenberg et al., 2001; Hoover-Dempsey \& Sandler, 2007; Rubie-Davies et al., 2010). On the other hand, Rubie-Davis et al. (2010) stated that the beliefs of children about academic achievement should not be harmed because of inaccurate parental expectations. They emphasize that unrealistic parental expectations may negatively affect academic achievement. Moreover, as Başar (2001) and Carney-Hall (2008) emphasized, unrealistically high expectations may cause the child to feel excessive pressure and responsibility and to 
experience failure and disappointment. In the present study, it was revealed that family's SES, parents' educational status, PI practices at home, and parents' educational expectations are important variables in explaining academic achievement. At the same time, the most outstanding result of the present study is that parental expectations were found to be the most important predictor of academic achievement when compared to all other variables.

The results of the present study offer several more insights for parents, principals, and researchers. As mentioned above, the most important predictor of academic achievement is the expectations of parents about their child's education. For this reason, it is important for parents to monitor their children's academic development and achieve the necessary knowledge to help them establish realistic expectations about their children and discuss them with their children. However, for the parents to establish realistic expectations among themselves and with their children about school and education, communication with teachers is an important information source. Besides that, it is especially important that parents with a low educational status are supported by teachers, schools, and other institutions so that they can access information sources about their children's development and education.

Since the features and characteristics of each school and family are different, it is important to analyze possible risk factors for the planning, implementation, and effectiveness of PI programs. In the analysis, to ensure the effectiveness of programs, it is also necessary to focus not only on school-based but also on involvement practices at home. As mentioned above, parents may need support, training, develop communication skills, and information enabling them to create realistic expectations about their children. In this regard, principals and teachers have a significant role in creating an effective PI environment for all.

Finally, with reference to the results obtained from this research, there are several issues that have been handled in detail by the researchers. In the Turkish literature, it is believed that studies should examine academic success within the scope of parental cognitions and academic socialization through qualitative research methods and techniques in detail. In 
conclusion, it has been argued that parental expectation is an important predictor of academic achievement. Therefore, it is necessary to present the relationship of this variable to academic achievement in further detail through longitudinal studies to be conducted at different educational levels.

\section{Statement for Ethical Issues}

We confirm that all aspect of the research covered in this manuscript that has involved human has been conducted with the ethical rules. The authors also declared that they did not use any references other than those given in the References section and the manuscript has not been sent to another journal for review or publication.

\section{Conflict of Interest Statement}

The authors declare that the research was conducted in the absence of any commercial or financial relationships that could be construed as a potential conflict of interest.

\section{Kaynakça/References}

Aktamış H., Ünal G., \& Ergin Ö. (2008). Öğrencilerin fene yönelik tutumlarına ailelerinin etkisi. Aile ve Toplum, (4)14, 39-48. Retrieved February 2017, from https://dergipark.org.tr/tr/download/article-file/198097

Amatea, E., \& West-Olatunji, C. (2007). Joining the conversation about educating our poorest children: Emerging leadership roles for school counselors in high-poverty schools. Professional School Counseling, 11(2), 81-89. Retrieved April 2017, from http://www.jstor.org/stable/42732787

Argon, T. \& Kıyıcı, C. (2012). Illköğretim kurumlarında ailelerin eğitim sürecine katılımlarına yönelik öğretmen görüşleri. Dicle Üniversitesi Ziya Gökalp Eğitim Fakültesi Dergisi, 19, 80-95. Retrieved June 2017, from https://dergipark.org.tr/tr/pub/zgefd/issue/47945/606598 
Başar, M. (2001). Ailelerdeki yanlış başarı algılamasının öğrenciler üzerindeki etkileri. Afyon Kocatepe Üniversitesi Sosyal Bilimler Dergisi, 2(2), 115-124. Retrieved February 2018, from https://sbd.aku.edu.tr/II2/10-murat-basar.pdf

Batyra, A. (2017). Türkiye'de cinsiyete dayalı başarı farkı. Aydın Doğan Vakfı. Eğitim Reformu Girişimi. Retrieved February 2018, from https://aydindoganvakfi.org.tr/static/media/images/files/PISA_TR.pdf.

Carney-Hall, K. C. (2008). Understanding current trends in family involvement. New Directions for Student Services (122), 3-14. https://doi.org/10.1002/ss.271

Carpenter, D. M. (2008). Expectations, aspirations, and achievement among Latino students of immigrant families. Marriage \& Family Review, 43(1/2), 164-185. https://doi.org/10.1080/01494920802013078

Clinton, J. \& Hattie, J. (2013). New Zealand students' perceptions of parental involvement in learning and schooling. Asia Pacific Journal of Education, 33(3), 324-337. https://doi.org/10.1080/02188791.2013.786679

Comer, J. P. \& Haynes, N. M. (1991). Parent involvement in schools: An ecological approach. The Elementary School Journal, 91(3), 271-277. https://doi.org/10.1086/461654

Çelenk, S. (2003). Okul başarısının ön koşulu: Okul aile dayanışması. Illköğretim Online E-dergi, 2(2), 28-34. Retriewed November 2017, from http://ilkogretimonline.org.tr/vol2say2/v02s02d.pdf at 15.12.2018

Çokluk, Ö. (2010). Lojistik regresyon analizi: Kavram ve uygulama. Kuram ve Uygulamada Eğitim Bilimleri, 10(3), 1357-1407. Retrieved January 2018, from http://www.edam.com.tr/kuyeb/pdf/tr/3e2b1f84ce847e4fef09b68db9b1a420kFULL.pdf Çokluk, Ö., Şekercioğlu, G. \& Büyüköztürk, Ş. (2014). Sosyal bilimler için çok değişkenli istatistik: SPPS ve LISREL uygulamaları. Pegem Academy. 
Çubukçu, Z., \& Girmen, P. (2006). Ortaöğretim kurumlarının etkili okul özelliklerine sahip olma düzeyleri. Manas Üniversitesi Sosyal Bilimler Dergisi, 16, 121-136. Retrieved May 2017, from https://dergipark.org.tr/tr/download/article-file/843732

Davis-Kean, P. E. (2005). The influence of parent education and family income on child achievement: The indirect role of parental expectations and the home environment. Journal of Family Psychology, 19(2), 294-304. https://doi.org/10.1037/08933200.19.2.294

Daymaz, S. (2012). The analysis of the relationship between 7th grade of primary school students' parents' expectations and the test anxiety (Unpublished Master Thesis). Istanbul: University of Yeditepe.

Deslandes, R. (Ed.). (2009). International perspectives on contexts, communities and evaluated innovative practices: Family-school-community partnerships. Routledge.

Duan, W., Guan, Y. \& Bu, H. (2018). The effect of parental involvement and socioeconomic status on junior school students' academic achievement and school behavior in China. Frontiers in Psychology, 9 (952). https://doi.org/10.3389/fpsyg.2018.00952

Englund, M. M., Luckner, A. E., Whaley, G. J. L. \& Egeland, B. (2004). Children's achievement in early elementary school: Longitudinal effects of parental involvement, expectations, and quality of assistance. Journal of Educational Psychology, 96(4), 723-730.

https://doi.org/10.1037/0022-0663.96.4.723

Epstein, J. L. (2010). School/family/community partnerships: Caring for the children we share. Phi Delta Kappan, 92 (3), 81-96. Retrieved May 2018, from https://scihub.se/10.1177/003172171009200326

Epstein, J. L. (2008). Improving family and community involvement in secondary schools. Principal Leadership, 8(2), 16-22. 
Fan, X., \& Chen, M. (2001). Parental involvement and students' academic achievement: A meta-analysis. Educational Psychology Review, 13 (1), 1-22. DOI: https://doi.org/10.1023/A:1009048817385

Flaxman, E., \& Inger, M. (1991). Parents and Schooling in the 1990s. The ERIC Review, 1 (3), 26.

Flynn, G. V. (2007). Increasing parental involvement in our schools: The need to overcome obstacles, promote critical behaviors, and provide teacher training. Journal of College Teaching \& Learning, 4(2), 23-30. https://doi.org/10.19030/tlc.v4i2.1627

Goldenberg, C., Gallimore, R., Reese, L. \& Garnier, H. (2001). Cause or effect? Study of immigrant Latino parents' aspirations and expectations and their children's school performance. American Educational Research Journal, 38(3), 547-582. https://doi.org/10.3102/00028312038003547

Gonzales-DeHass, A. R., Willems, P. P. \& Holbein, M. F. D. (2005). Examining the relationship between parental involvement and student motivation. Educational Pyschology Review, 17(2), 99-123. https://doi.org/10.1007/s10648-005-3949-7

Graue, E., \& Brown, C. P. (2003). Preservice teachers' notions of family and schooling. Teaching and Teacher Education, 19(7), 719-735. https://doi.org/10.1016/j.tate.2003.06.002

Green, C. L., Walker, J. M. T., Hoover-Dempsey, K. V. \& Sandler, H. (2007). Parents' motivations for involvement in children's education: An empirical test of a theoretical model of parental involvement. Journal of Educational Psychology, 99, 532-544. https://doi.org/10.1037/0022-0663.99.3.532

Gurdal, S. (2015). Children and Parents-Attributions, Attitudes and Agency. Retrieved May 2020, from https://gupea.ub.gu.se/handle/2077/39348

Hill, N. E. \& Tyson, D. F. (2009). Parental involvement in middle school: A meta-analytic assessment of the strategies that promote achievement. Developmental Psychology, 45(3), 740-763. DOI: 10.1037/a0015362 
Hoover-Dempsey, K. V., Walker, J. M. T., Sandler, H. M., Whetsel, D., Green, C. L., Wilkins, A. S., et al. (2005). Why do parents become involved? Research findings and implications. The Elementary School Journal, 106(2), 105-130. https://doi.org/10.1086/499194

Hornby, G. (2011). Parental involvement in childhood education: Building effective schoolfamily partnerships. Springer.

Hornby, G. \& Lafaele, R. (2011). Barriers to parental involvement in education: An explanatory model. Educational Review, 63(1), 37-52.

https://doi.org/10.1080/00131911.2010.488049

Iflazoğlu-Saban, A.I. \& Şeker, M. (2010). Illköğretim 5.sınıf öğrencilerinin performans görevlerindeki başarıları ile ailelerin eğitim öğretim çalışmalarına katılım düzeyleri arasındaki ilişkinin belirlenmesi. Ç.Ü. Sosyal Bilimler Enstitüsü Dergisi, 19(3),361-390. Retrieved May 2018, from https://dergipark.org.tr/tr/download/article-file/50635 Jacobs, J. E., Davis-Kean, P., Bleeker, M., Eccles, J. S., \& Malachuk, O. (2005). I can, but I don't want to: The impact of parents, interests, and activities on gender differences in math. In Gallagher, M. Ann, J. C. Kaufman (Eds.), Gender differences in mathematics: An integrative psychological approach (pp. 246-263). New York, NY: Cambridge University Press.

Jeynes, W. H. (2007). The relationship between parental ınvolvement and urban secondary school student academic achievement: A meta-analysis. Urban Education, 42(1), 82-110. https://doi.org/10.1177/0042085906293818

Jeynes, W. H. (2011). Parental involvement and academic success. Routledge.

Kaya, Ö. \& Bacanlı, H. (2016). Eğitim yaşantısına ebeveyn katılım algısını açıklamaya yönelik bir model geliştirme. Hacettepe Üniversitesi Eğitim Fakültesi Dergisi, 31(2), 410-423. https://doi.org/10.16986/HUJE.2015014092 
Kim, S. W. (2018). How and why fathers involved in their children's education: gendered model of parent involvement. Educational Review, 70 (3), 280-299. https://doi.org/10.1080/00131911.2017.1311304

Kirk, C. M., Lewis-Moss, R. K., Nilsen, C. \& Colvin, D. Q. (2011). The role of parent expectations on adolescent educational aspirations. Educational Studies, 37 (1), 89-99. https://doi.org/10.1080/03055691003728965

Kotaman, H. (2008). Türk ana babalarının çocuklarının eğitim öğretimlerine katılım düzeyleri. Uludağ Üniversitesi Eğitim Fakültesi Dergisi, 21(1), 135-149. Retrieved May 2018, from https://dergipark.org.tr/tr/pub/uefad/issue/16687/173409

Lam, B. T. \& Ducreux, E. (2013). Parental influence and academic achievement among middle school students: Parent perspective. Journal of Human Behaviour in the Social Environment, 23(5), 579-590. https://doi.org/10.1080/10911359.2013.765823

LaRocque, M., Kleiman,I., Darling, S.M. (2011). Parental involvement: The missing link in school achievement. Preventing School Failure, 55(3), 115-122. https://doi.org/ $10.1080 / 10459880903472876$

Lee, S. M., Kushner, J., \& Cho, S. H. (2007). Effects of parent's gender, child's gender, and parental involvement on the academic achievement of adolescents in single parent families. Sex roles, 56(3), 149-157. https://doi.org/10.1007/s11199-006-9157-1

Lenz, C. R. (1999). The effects of family influence on motivation and achievement of low socioeconomic Latino and African-American elementary school students (Doctoral thesis). St. John's University, New York.

Lindberg, E.N., Yildirim, E., Elvan, O., Ozturk, D. \& Recepoglu, S. (2019). Parents' educational expectations: Does it matter for academic success?. SDU International Journal of Educational Studies, 6(2), 150-160. https://doi.org/10.33710/sduijes.596569 
Liu, J. \& Lynn, R. (2015). Chinese sex differences in intelligence: Some new evidence.

Personality and Individual Differences, 75, 90-93.

https://doi.org/10.1016/j.paid.2014.11.002

Mistry, R., White, E., Benner, A. \& Huynh, V. (2009). A longitudinal study of the simultaneous influence of mothers' and teachers' educational expectations on low-income youth's academic achievement. Journal of Youth and Adolescence, 38, 826-838. https://doi.org/ $10.1007 / \mathrm{s} 10964-008-9300-0$

Morera, M. C., Exposito, E., Lopez-Martin, E. \& Lizasoain, L. (2015). Parent involvement on student academic achievement: A meta-analysis. Educational Research Review, 14, 3346. https://doi.org/10.1016/j.edurev.2015.01.002

Neuenschwander, M. P., Vida, M., Garret, J. L., \& Eccles, J. (2007). Parent's expectations and students' achievement in two western nations. International Journal of Behavioral Development, 31(6), 594-602. https://doi.org/10.1177/0165025407080589

Oğuz, K. (2012). ilköğretim okullarında aile katılımı: Ölçek uyarlaması (Unpublished master thesis). Kastamonu Universitesi, Sosyal Bilimler Enstitüsü, Kastamonu.

Patrikakou, E.N. (2008). The power of parent involvement: Evidence, ideas, and tools for student success. Lincoln, IL: The Center on Innovation and Improvement. Retrieved May 2018, from http://www.centerii.org/search/Resources/PowerParInvolve.pdf

Pavalache-Ilie, M. \& Tirdia, F. A. (2015). Parental involvement and intrinsic motivation with primary school students. Procedia Social and Behavioral Sciences, 187, 607-612. https://doi.org/10.1016/j.sbspro.2015.03.113

Pong, S., Hao, L. \& Gardner E. (2005). The roles of parenting styles and social capital in the school performance of immigrant Asian and Hispanic adolescents. Social Science Quarterly, 86(4), 928-950. https://doi.org/10.1111/j.0038-4941.2005.00364.x 
Ramirez, A. Y. F. (2003). Dismay and disappointment: Parental involvement of Latino immigrant parents. Urban Review, 35, 93-110. https://doi.org/10.1023/A:1023705511946

Rubie-Davies, C. M., Peterson, E., Irving, E., Widdowson, D. \& Dixon, R. (2010). Expectations of achievement: Student, teacher and parent perceptions. Research in Education, 83, 3653. https://doi.org/10.7227/RIE.83.4

Räty, H., Leinonen, T., \& Snellman, L. (2002). Parents' educational expectations and their socialpsychological patterning. Scandinavian Journal of Educational Research, 46 (2), 129-144. Retrieved May 2020, from http://blogs.ubc.ca/newproposals/files/2009/03/education_parents_expectation.pdf

Sabancı, A. (2009). Türkiye'de veli katılımına ilişkin ilköğretim okulu yöneticilerinin, öğretmenlerinin ve öğrenci velilerinin görüşleri. Eurasian Journal of Educational Research, 36(Yaz), 245-262.

Sarpkaya, P. (2007). Yönetici, öğretmen, öğrenci ve velilere göre resmi liselerdeki öğrenci disiplin sorunlarının nedenleri. Pamukkale Üniversitesi Eğitim Fakültesi Dergisi, 2 (22), 110-121. Retrieved May 2018, from https://dergipark.org.tr/tr/pub/pauefd/issue/11121/132998

Sheldon, S.B., Epstein, J.L. (2007). Student survey of family and community involvement in the elementary and middle grades. Baltimore: Johns Hopkins University, Center on School, Family, and Community Partnerships.

Stahl, J. D. (2012). Parental Involvement in Education. Retrieved May 2018, from http://www.jeffdstahl.com/worksfiles/parentalinvolvement.pdf Symeou, L. (2008). From school-family links to social capital: Urban and rural distinctions in teacher and parent networks in Cyprus. Urban Education, 43, 696-722. https://doi.org/10.1177/0042085907311825 
Şad, S.N. (2012). Investigation of parental involvement tasks as predictors of primary students' Turkish, Math and Science \& Technology achievement. Eurasian Journal of Educational Research, 49 (Fall), 173-196.

Şirin, S. R. (2005). Socioeconomic status and academic achievement: A meta-analytic review of research. Review of Educational Research, 75(3), 417-453.

https://doi.org/10.3102/00346543075003417

Tabachnick, B. G. \& Fidell, L. S. (2007). Using multivariate statistics. New York: Allyn and Bacon.

Taş, U. E., Arıcı, Ö., Ozarkan, H. B. \& Özgürlük, B. (2016). Uluslararasi öğrenci değerlendirme programi PISA 2015 ulusal raporu. Retrieved May 2018, from http://odsgm.meb.gov.tr/test/analizler/docs/PISA/PISA2015_Ulusal_Rapor.pdf

Vaden-Kiernan, N., \& Chandler, K. (1996). Parents' reports of school practices to involve families. National Center for Education Statistics, 1-15. Retrieved May 2018, from http://nces.ed.gov/pubs/97327.pdf.

Valsiner, J. (Ed.). (1988). Child development within culturally structured environments: Parental cognition and adult-child interaction. Ablex Publishing.

Vygotsky, L.S. (1978). Mind in Society. (Ed. M. Cole, V.Joh-Steiner, S. Scribner, E. Souberman). Harvard University Press.

Weber, A. (2010). Can family involvement improve educational outcomes in developing countries?. Retrieved February 2017, from: http://hdl.handle.net/10419/37533

Wilder, S. (2014). Effects of parental involvement on academic achievement: A meta synthesis. Educational Review, 66(3), 377-397. https://doi.org/10.1080/00131911.2013.780009

Yamamoto, Y. \& Holloway, S. D. (2010). Parental expectations and children's academic performance in sociocultural context. Educational Psychology Review, 22, 89-214. https://doi.org/10.1007/s10648-010-9121-z 
Yıldırım H. H., Yıldırım S., Ceylan, E. \& Yetişir, M. İ. (2013). Türkiye perspektifinden TIMSS 2011 sonuçları. Türk Eğitim Derneği Tedmem Analiz Dizisi I. Retrieved May 2018, from https://www.ted.org.tr/wp-content/uploads/2019/04/timmsarastirmaraporu.pdf

İletişim/Correspondence

Doç.Dr.E.Nihal LiNDBERG, ahioglu@kastamonu.edu.tr, nihal@lindberg.im Pınar GÜVEN, pinarguven37@hotmail.com 